\title{
Wikken en wegen
}

Citation for published version (APA):

Hillen, H. F. P. (1994). Wikken en wegen. Maastricht University. https://doi.org/10.26481/spe.19941014hh

Document status and date:

Published: 14/10/1994

DOI:

10.26481/spe.19941014hh

Document Version:

Publisher's PDF, also known as Version of record

\section{Please check the document version of this publication:}

- A submitted manuscript is the version of the article upon submission and before peer-review. There can be important differences between the submitted version and the official published version of record.

People interested in the research are advised to contact the author for the final version of the publication, or visit the DOI to the publisher's website.

- The final author version and the galley proof are versions of the publication after peer review.

- The final published version features the final layout of the paper including the volume, issue and page numbers.

Link to publication

\footnotetext{
General rights rights.

- You may freely distribute the URL identifying the publication in the public portal. please follow below link for the End User Agreement:

www.umlib.nl/taverne-license

Take down policy

If you believe that this document breaches copyright please contact us at:

repository@maastrichtuniversity.nl

providing details and we will investigate your claim.
}

Copyright and moral rights for the publications made accessible in the public portal are retained by the authors and/or other copyright owners and it is a condition of accessing publications that users recognise and abide by the legal requirements associated with these

- Users may download and print one copy of any publication from the public portal for the purpose of private study or research.

- You may not further distribute the material or use it for any profit-making activity or commercial gain

If the publication is distributed under the terms of Article $25 \mathrm{fa}$ of the Dutch Copyright Act, indicated by the "Taverne" license above, 


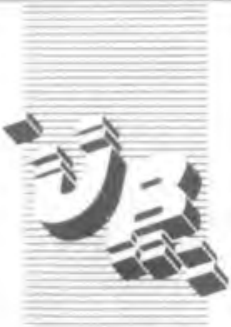

De uitleentermun verstrijkt op

\section{JAN, 1995}

Rıjksuniversıteıl Lımburg

Postbus 616

6200 MD Maastricht

Gelieve deze publicatie tijdig te retourneren of (telefonisch) verlen. ging van de uitleenlermijn aan te vragen

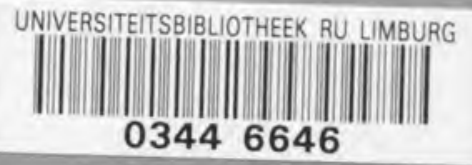




\title{
WIKKEN EN WEGEN
}

Rede

uitgesproken bij het aanvaarden van het ambt van hoogleraar in de Interne Geneeskunde in het bijzonder de Medische Oncologie aan de Rijksuniversiteit Limburg te Maastricht op 14 oktober 1994

door

\author{
Dr. H.F.P. Hillen
}


124583962

Bibliothenk

3.0. Zimbura

"Het leven is kort

de Kunst duurt voort;

maar het moment is zo voorbij, ervaring hachelijk

en oordelen steeds moeilijk"

Hippocrates

Aphorismen, Kos 406 v. Chr. 
Mijnheer de Rector Magnificus,

Dames en Heren,

Op het dorpsplein van Kos staat de oudste boom van Europa. Een wijdvertakte plataan die schaduw geeft onder de Griekse zon.

Het is de plaats waar Hippocrates 2400 jaar geleden het probleemgestuurd onderwijs in de geneeskunde tot ontwikkeling bracht.

De natuurlijke collegezaal bood uitzicht op de Egeïsche Zee in het Oosten en het Asklepion in het Westen. Het Asklepion was de kliniek van de School van Hippocrates, de Mayo Clinic van de klassieken, genoemd naar de god van de geneeskunde. In deze kliniek werden op drie uitgebreide terrassen patiënten onderzocht en behandeld.

Voor het eerst in de geschiedenis berustte daarbij diagnostiek en behandeling niet meer op religie of magie maar op precieze klinische waarnemingen. In deze periode werd de kline $(\kappa \lambda \iota \nu \eta)$, de onderzoeksbank in de geneeskunde, geïntroduceerd. Deze klinische waarnemingen zijn door Hippocrates nauwkeurig beschreven in publicaties die later zijn verzameld in het Corpus Hippocraticum.

De korte case reports in deze Proceedings van het Asklepion beginnen met het beroemde aphorisme: "Het leven is kort, de Kunst duurt voort; maar het moment is zo voorbij, ervaring is hachelijk en oordelen steeds moeilijk."

Deze uitspraak was toen kenmerkehd voor de Hippocratische geneeskunst en is nu even typerend voor de oncologie.

Het is verleidelijk om hier ook de etymologie van de oncologie op Kos, zogezegd on Cos, te zoeken, maar de afkomst is veel trivialer: namelijk de leer van de оүко, de leer van de gezwellen ofwel de knobbelkunde. 
Als wetenschap is de oncologie relatief jong. Desondanks kunnen, zoals in de eerste regels van het aphorisme, alle facetten en alle kennis van de oncologie niet meer in én leven verzameld worden. Het is niet mogelijk voor een oncoloog om alleen alle aspecten van het vak te overzien. Daarvoor is samenwerking van verschillende disciplines, ieder met een eigen deskundigheid, noodzakelijk. Multidisciplinaire oncologie is dan ook een centraal thema, dat niet beter kan worden gesymboliseerd dan door de gezamenlijke inauguratie van een chirurgisch en een medisch oncoloog aan deze universiteit.

Het vluchtige moment wordt bepaald door de beperkte tijd, meestal in het begin van de ziekte, waarin de behandeling van kanker het beste mogelijk is. Op dat moment moet dan wel de nodige deskundigheid voor een optimale behandeling beschikbaar zijn. In mijn verdere betoog wil ik beargumenteren dat daarvoor een taakverdeling in de oncologie onontbeerlijk is.

En dan de hachelijke ervaring en het moeilijke oordeel. Door de systematische waarnemingen aan het ziekbed was het voor Hippocrates duidelijk dat het beloop van ziekten niet werd bepaald door de goden of door de stand van de sterren, maar door de veranderlijke natuur van de mens zelf. Iedere patiënt reageert afhankelijk van zijn voorgeschiedenis en zijn omgeving anders en uniek op iedere ziekte. Immers, de ene mens is de andere niet. Deze individuele variatie verschafte vooralsnog weinig absolute zekerheden in de geneeskunde.

De vier-elementen leer van de Griekse geneeskunde, waarin ziekte werd beschouwd als een verstoring van het evenwicht in de vier lichaamssappen: bloed, slijm, gele gal en zwarte gal, bood te weinig wetenschappelijk inzicht om de variabiliteit van het ziektebeloop te verklaren. Daarom werd op Kos gekozen voor de empirische, stochastische benadering. 
De leerlingen van Hippocrates werden opgeleid in het waarnemen van symptomen. 's Morgens werden de patiënten in het Asklepion uitvoerig onderzocht, waarbij de klassieke dokters al hun zintuigen inzetten.

Zij observeerden precies, ausculteerden met het oor direct op de thorax en palpeerden, blijkens de beschrijvingen, zorgvuldig. Bij de palpatie van een gezwel beschreef Hippocrates de gelijkenis met een krab, de к $\alpha \rho \kappa \iota \nu о \sigma$, waarmee voor het eerst de term kanker in de literatuur verscheen.

$\mathrm{Na}$ het kijken, luisteren en voelen waren de Asklepiaden gewoon om bloed en urine even te proeven, en om de geur en de consistentie van excrementen vast te leggen op kleitabletten. De waarnemingen werden in de loop van de dag besproken. De betekenis van de symptomen voor het beloop van de ziekte werd ingeschat. De facies Hippocratica werd geduid als een omineus teken. Er werd overwogen wat bekend was over de behandeling bij soortgelijke symptomen.

Na rijp beraad werd een uitspraak gedaan over de prognose en de behandeling. Het wikken en wegen onder de plataan van Hippocrates.

Het zorgvuldig afwegen van voor- en nadelen van een behandeling is ook nu een essentieel onderdeel van de oncologische praktijk. Veel succesvolle behandelingen zijn via het principe van de empirie tot stand gekomen. Geleidelijk ontstate echter in de oncologie een groeiend inzicht in de mechanismen die van gezonde cellen kankercellen maken. Deze inzichten op het gebied van de celkinetiek en tumorbiologie zullen in de nabije toekomst het proces van wikken en wegen in de oncologie aanzienlijk kunnen beïnvloeden. $\mathrm{Er}$ is toenemende aandacht voor het onderzoek naar meetbare factoren die het mogelijk maken om bij individuele patiënten met kanker, preciezer dan tot nu toe, voorspellingen te doen over het beloop van de ziekte en over het resultaat van de behandeling. Ook in onze groep heeft het onderzoek naar deze 
prognostische factoren een centrale plaats. Enkele aspecten van de besluitvorming, het wikken en wegen, in de oncologie en de mogelijke rol van prognostische factoren daarbij zal ik verder toelichten.

\section{De Kunst duurt voort}

\section{Oncologie in Nederland}

Kanker is een aanzienlijk probleem in de Nederlandse gezondheidszorg. Ongeveer 220.000 Nederlanders leven nu met de diagnose kanker. Het aantal nieuwe patiënten per jaar bedraagt momenteel 60.000 (28.500 vrouwen en 31.500 mannen). De kans dat een Nederlandse man kanker krijgt vo6r zijn 75 e jaar is $30 \%$, voor vrouwen is dit percentage lager, maar nog steeds indrukwekkend: $22 \%$.

Kanker is aan de leeftijd gebonden. Met stijgende leeftijd neemt de incidentie toe. Dit heeft twee belangrijke consequenties: Dertig procent van alle nieuwe patiënten met kanker is ouder dan 75 jaar en als gevolg van de vergrijzing van de bevolking neemt het aantal patiënten ieder jaar met $1,5 \%$ toe. De Scenariocommissie Kanker van de Gezondheidsraad houdt rekening met een voortdurende stijging wanneer de na-oorlogse "baby-boom" generatie op leeftijd komt tot het jaar 2020.

De zorg voor patiënten met kanker staat in Nederland op een hoog peil. Dankzij het werk van de kankerregistratie van het Integraal Kankercentrum Zuid, onder leiding van Dr. J.W.W. Coebergh, en de kankerregistratie van het Integraal Kankercentrum Limburg, onder leiding van Drs. L.J. Schouten, beschikken wij in Nederland over betrouwbare gegevens betreffende de incidentie en de 
overleving.

De gemiddelde kans om in ons land 5 jaar na het stellen van de diagnose een invasieve maligniteit te overleven, is $42 \%$. Voor vrouwen is dit percentage $51 \%$ en voor mannen $33 \%$, waarbij het verschil vooral verklaard wordt door de sterfte aan longkanker bij mannen. Bij de berekening van deze 5 -jaarsoverleving zijn de goed behandelbare kankers van de huid buiten beschouwing gebleven, en zijn de getallen gecorrigeerd voor de verwachte sterfte aan andere doodsoorzaken. De totale 5-jaarsoverleving en de 5-jaarsoverleving per tumorsoort zijn in Nederland hetzelfde als in West-Europa en de Verenigde Staten.

In Nederland wordt relatief weinig geld besteed aan de behandeling van kanker. In 1988 werd in totaal bijna 1900 miljoen gulden uitgegeven aan de oncologische zorg, dit is $4,6 \%$ van de totale kosten van de gezondheidszorg. In de Verenigde Staten was dit percentage in 1980 al $6,2 \%$, in Zweden $5,1 \%$.

\section{Medische Oncologie}

De huidige diagnostiek en de behandeling van kanker worden uitgevoerd door een multidisciplinair team. In de diagnostische fase spelen de radiodiagnostiek en de pathologie een belangrijke rol. Ruim $70 \%$ van de patiënten komt voor een operatieve behandeling bij én van de chirurgische disciplinet. Mijn mede-inaugurator zal $\mathrm{U}$ hierover uitvoerig informeren. $\mathrm{Na}$ de diagnose of in de loop van het ziektebeeld wordt $50 \%$ van de patiënten bestraald door de radiotherapeut. Ongeveer $25 \%$ van alle patiënten wordt vroeg of laat behandeld met chemotherapie.

Chemotherapie is de behandeling van kanker met celremmende geneesmiddelen. Deze vorm van behandeling is bij uitstek het deskundigheidsgebied van de medische oncologie. Het bijzondere vak van de medisch-oncoloog omvat behalve chemotherapie ook de 
diagnostiek, de supportieve zorg en de psychosociale begeleiding van patiënten met kanker. Vaak vervult de medisch-oncoloog een coördinerende rol bij de multidisciplinaire behandeling.

Sinds 1988 bestaat een registratie en een opleiding voor het aandachtsgebied medische oncologie binnen de interne geneeskunde. Deze opleiding, die 2 jaar duurt, kan worden gevolgd aan de meeste academische ziekenhuizen. Ook onze afdeling heeft een opleiding medische oncologie, waarin kollega Lalisang jr. gekoesterd wordt.

De Nederlandsche Internisten Vereeniging heeft in de jaren ' 80 langdurig gewikt en gewogen of het niet wenselijk zou zijn een apart zelfstandig specialisme medische oncologie, los van de interne geneeskunde, in te stellen. $\mathrm{Na}$ overleg met het Centraal College van de Specialisten Registratie Commissie is terecht gekozen voor het aandachtsgebied binnen de interne geneeskunde, op grond van drie essentiële argumenten. Inhoudelijk wordt de medische oncologie beschouwd als een typisch internistisch vak, dat beperkter en armer zou worden, wanneer de andere facetten van de interne geneeskunde daarin onvoldoende aan bod zouden komen. In de dagelijkse praktijk wordt de medisch-oncoloog geconfronteerd met infektieziekten, nierfunktiestoornissen, problemen van water- en zouthuishouding, afwijkingen in het kalkmetabolisme en complicaties op het gebied van de haemostase en thrombose. Het tweede argument is van logistieke aard. Door de incorporatie in de interne geneeskunde is vestiging van medischoncologen in maatschappen van internisten mogelijk, waardoor de spreiding en de bereikbaarheid van oncologische zorg aanzienlijk wordt bevorderd. Het derde argument is van algemene aard. Door de instelling van aandachtsgebieden wordt de voor de gezondheidszorg ongewenste verbrokkeling van de interne geneeskunde voorkomen. Op dit moment zijn 164 internisten geregistreerd met het aandachtsgebied medische oncologie. Honderd van deze internisten werken in grote internisten- 
maatschappen in niet-universitaire ziekenhuizen. Voor de medischoncologen, die werkzaam zijn in academische ziekenhuizen, is differentiatie en uitbreiding van de opleiding noodzakelijk. Hiervoor is echter geen aparte opleidingsstructuur nodig. Inmiddels wordt in Europa, waar gestreefd wordt naar een harmonisatie van de specialistenopleiding, met afgunst gekeken naar het Nederlandse systeem.

\section{Multidisciplinaire Oncologie}

Om patiënten met kanker zo goed mogelijk te behandelen, is een optimale samenwerking tussen de verschillende disciplines noodzakelijk. Daarom getuigt het van visie dat de Raad van Bestuur van het Academisch Ziekenhuis Maastricht onlangs zijn goedkeurig heeft gegeven aan de instelling van een Zwaartepunt Oncologie in het azM. Binnen dit samenwerkingsverband kunnen de krachten op het gebied van onderzoek, onderwijs en patiëntenzorg gebundeld worden. Door de extra ondersteuning van het Zwaartepunt kunnen nieuwe ontwikkelingen ter hand worden genomen. Eén van deze ontwikkelingen betreft de organisatie van een multidisciplinaire polikliniek oncologie. Op deze polikliniek kunnen patiënten door meerdere specialisten worden gezien, zodat advies en beleid tot stand komen na wikken en wegen vanuit verschillende gezichtspunten. Behandelingen door meerdere disciplines kunnen binnen dit kader goed op elkaar worden afgestemd. Verpleegkundige zorg en psychosociale ondersteuning worden binnen de multidisciplinaire polikliniek oncologie vanzelfsprekend in de behandeling geïntegreerd. Tenslotte kan de multidisciplinaire polikliniek een ondersteunende en adviserende funktie vervullen bij de thuiszorg van patiënten met kanker. 


\section{De KOS in Limburg, het optimale moment}

\section{Taakverdeling in de Oncologie}

De structuur van de oncologische zorg moet uiteindelijk zodanig georganiseerd worden, dat elke individuele patiënt een zo goed mogelijke behandeling krijgt op de plaats die daarvoor het meest geschikt is. Het beperkte budget maakt het bovendien noodzakelijk zo doelmatig mogelijk gebruik te maken van de beschikbare voorzieningen. Daarvoor is behalve multidisciplinaire samenwerking binnen ziekenhuizen ook een taakverdeling in de oncologie tussen verschillende ziekenhuizen noodzakelijk. In februari 1993 heeft de Commissie "Taakverdeling Oncologische Zorg" van de Gezondheidsraad hierover een advies uitgebracht. De kern van dit advies is: "Spreiding van zorg waar maar mogelijk, en concentratie waar nodig." De noodzaak van taakverdeling in de medische oncologie volgt uit de epidemiologie van de verschillende vormen van kanker. In het gebied van het Integraal Kankercentrum Limburg worden per jaar, verdeeld over 7 ziekenhuizen, 3300 nieuwe patiënten gezien. Van de 52 soorten kanker die bij deze 3300 patiënten worden gevonden, komen 32 soorten minder dan 35 keer per jaar voor, dus minder dan 5 patiënten per jaar per ziekenhuis. Wanneer de eventuele behandeling van deze patiënten verspreid blijft over de 7 ziekenhuizen, dan is geen van de betrokken behandelaars in staat om voldoende expertise en ervaring op te bouwen. Een goed voorbeeld vormen de testistumoren bij mannen. Hiervoor bestaat intensieve en zeer effectieve behandeling. Het lijkt vanzelfsprekend de 16 patiënten, die per jaar in het IKL-gebied voorkomen, in eén instituut te concenteren. Voor de optimale behandeling van de 70 patiënten met een non-Hodgkin lymfoom is een ander verdelingsmodel goed denkbaar. Diagnostiek en behandeling vergen extra deskundigheid, die zeker in de grotere 
ziekenhuizen in de regio voortreffelijk aanwezig is. Verdere concentratie is daarom alleen voor die patiënten, waarbij beenmergtransplantatie wordt overwogen, nodig. De behandeling van veel voorkomende maligniteiten als borstkanker (551) en dikkedarmkanker (266) hoort in ieder ziekenhuis van de regio goed te kunnen plaatsvinden. Ook in deze groep is concentratie van de zorg denkbaar voor die patiënten, die in aanmerking komen voor vernieuwende behandeling. Daarvoor is klinisch-wetenschappelijk onderzoek nodig, de typische funktie van een academisch centrum in de regio.

Inhoudelijk is het advies voor taakverdeling uitstekend, maar in de praktijk blijkt dit advies moeilijk te realiseren. Daarvoor moet bereikt worden dat de grenzen die tussen verschillende ziekenhuizen bestaan, en de grenzen die tussen verschillende behandelteams bestaan, geleidelijk geslecht worden. Het Integraal Kankercentrum Limburg kan daarbij een belangrijke rol spelen. In de besprekingen van de tumorwerkgroepen, die tot nu toe vooral gericht waren op het formuleren van richtlijnen voor diagnostiek en behandeling, moet ook een plaats ingeruimd worden voor de taakverdeling. Het wikken en wegen over de optimale plaats van de behandeling moet er in feite toe leiden dat de groep van medischoncologen in de regio als én geheel gaat funktioneren. In de regio van het IKL moet een dergelijke integrale benadering met perifere corifeeën als Wils, Fickers, Bron en onze eigen eerste aandachtsgebieder Erdkamp, uitstekend mogelijk zijn. Onze Werkgroep zal zich in ieder geval sterk maken voor het realiseren van de KOS in Limburg, een Klinisch-Oncologische Samenwerking, waarbij ons een strategische alliantie voor ogen staat, die winst moet opleveren voor alle betrokken deelnemers. De schaduw van én van de grote bomen op het Vrijthof lijkt een perfekt plaats voor de alliantie vergaderingen. 


\section{Het Moeilijke Oordelen, Wikken en Wegen}

\section{Onderzoek naar Prognostische Faktoren}

De dagelijkse praktijk van de medische oncologie wordt gekenmerkt door veel overleg. Overleg in tumorwerkgroepen over protocollen voor bepaalde tumoren, overleg in de oncologiebespreking over het behandeladvies voor én bepaalde patiënt, en vooral overleg met patiënten, over al of niet behandelen en over het soort behandeling. De besluitvorming, die tijdens dit overleg plaatsvindt, is stochastisch van aard. Waarschijnlijkheid en inschatting van kansen spelen daarbij een overheersende rol.

Ik zal dit proberen te illustreren aan de hand van de ziektegeschiedenis van een jonge vrouw met borstkanker. Zij onderging in 1989 een borstsparende operatie in verband met een tumor van $2 \mathrm{~cm}$ in de linker borst. Bij de operatie werden 16 lymfklieren uit de oksel verwijderd. In 4 hiervan werden metastasen van een mammacarcinoom gevonden. Patiënte herstelde voorspoedig en bij het onderzoek na de operatie waren er geen aanwijzingen dat er nog tumor was achtergebleven.

Uit onderzoek is echter bekend dat er een direkte relatie bestaat tussen het aantal okselklieren met metastasen en het latere beloop van de ziekte. Ondanks de geslaagde operatie, worden bij $35 \%$ van de patiënten met positieve okselklieren binnen 5 jaar metastasen op afstand gevonden en dit percentage neemt toe tot $70 \%$ binnen 10 jaar. Vrijwel alle patiënten, waarbij metastasen op afstand worden gevonden, overlijden ten gevolge van het mammacarcinoom. Dit risico was aanleiding om met patiënte te praten over verdere behandeling. Inmiddels is namelijk aangetoond dat het risico op het ontstaan van metastasen door behandeling met chemotherapie, in aansluiting aan de operatie, kan worden verminderd met $36 \%$. Deze waarschijnlijkheidsgetallen berusten op empirisch onderzoek 
bij meer dan 10.000 patiënten. Onze patiënte was echter weinig geïnteresseerd in statistiek en vroeg mij meteen of ik haar kon vertellen of bij haar wél of geen metastasen zouden ontstaan en of de adjuvante chemotherapie, die ik voorstelde, bij haar zeker zou werken.

Op dit moment beschikt de medische oncologie nog niet over meetmethoden die het mogelijk maken om per patiënt de prognose en het resultaat van een bepaalde behandeling met zekerheid te voorspellen. Het onderzoek naar betrouwbare prognostische faktoren staat echter volop in de belangstelling. Een belangrijk gedeelte van het klinisch-wetenschappelijk onderzoek van de Werkgroep Haematologie-Oncologie in Maastricht, is gericht op dit onderwerp.

\section{Tumorproliferatie}

Pierre Hupperets heeft onder leiding van mijn illustere voorganger Geert Blijham onderzoek gedaan naar de prognostische waarde van DNA flowcytometrie bij het mammacarcinoom. Flowcytometrie is een techniek, waarmee in korte tijd het DNA-gehalte van 2030.000 tumorcellen gemeten kan worden. De meting resulteert in een DNA-verdelingshistogram van de gemeten celpopulatie. Normale cellen hebben in rust een DNA hoeveelheid, die overeenkomt met 23 chromosomenparen. Deze $\mathrm{G}_{1}$-cellen worden afgebeeld in de $2 n$-piek van het histogram. In delende cellen wordt de DNA hoeveelheid geleidelijk verdubbeld, zodat het percentage cellen met meer dan 2n-DNA in een histogram een maat is voor de delingsaktiviteit van het weefsel. In tumorweefsel wordt echter naast de normale $G_{1}$-piek vaker een groep cellen gemeten met een abnormale hoeveelheid DNA in rust. Deze aneuplö̈de cellen vertegenwoordigen de populatie van cellen in de tumor, waarin aanzienlijke genetische afwijkingen bestaan. In het onderzoek van 
Hupperets wordt bij $60 \%$ van de mammatumoren een aneuploïde piek gevonden. Voor de kliniek is van belang dat bij patiënten met een aneuploïde tumor het risico voor het ontwikkelen van metastasen 2 tot 3 keer hoger is dan bij de patiënten zonder aneuploïdie. De flowcytometrie biedt op die manier een eerste mogelijkheid om per tumor meer inzicht te krijgen in de prognose.

De abnormale celdeling in tumoren wordt gestuurd door het DNA in de celkern. Bij die sturing maakt het DNA gebruik van boodschapper-eiwitten, die in de cel de deling kunnen remmen of bevorderen. Het flowcytometrie-onderzoek wordt door Rob Jansen uitgebreid met de meting van deze eiwitten, waarvan PCNA en het p53 eiwit voorbeelden zijn. De prognostische betekenis van deze metingen staat nog niet vast. De hypothese is echter dat de meeste maligne cellen, die kunnen uitzaaien, gekenmerkt worden door aneuploïdie, expressie van abnormaal p53 en een hoog PCNA gehalte. Het is aannemelijk dat het percentage van deze cellen in een tumor de prognose mede bepaalt.

\section{Angiogenese}

Om te kunnen groejen heeft een tumor voedingsstoffen nodig. Voor het aanvoeren hiervan worden in de tumor nieuwe hloedvaatjes gevormd, de zogenaamde angiogenese. Deze nieuwe vaatjes maken niet alleen verdere tumorgroei mogelijk, maar vormen ook de meest fragiele bloedvaatjes in de tumor, waarvan de wand doorlaatbaar is voor tumorcellen en daardoor de toegangspoort vormt voor de metastasering op afstand. Er zijn technieken ontwikkeld om deze nieuwe bloedvaatjes in tumoren te meten. In het onderzoek van Hupperets en Jansen wordt gekeken of er een verband bestaat tussen het aantal nieuwe bloedvaatjes in mammatumoren en de prognose. De hypothese is dat tumoren, waarin veel capillairen worden gevonden, gemakkelijk metastaseren. Bovendien bestaan er aanwijzingen dat de druk in 
vaatrijke tumoren hoger is, waardoor geneesmiddelen moeilijker doordringen in de tumor. Hoge microvascularisatie zou op die manier kunnen samenhangen met resistentie voor chemotherapie.

Naast het klinisch onderzoek naar angiogenese wordt laboratoriumonderzoek op dit gebied ontwikkeld. Annemarie Janson en Puck Muller doen in het Researchlaboratorium Oncologie onderzoek naar angiogenese in een kweekmodel. Het is mogelijk vaatnieuwvorming te induceren in kweken van endotheelcellen. In deze kweken kan de invloed van tumorcellen of van angiogene groeifaktoren uit tumorcellen gemeten worden. Onze belangstelling gaat hierbij in eerste instantie uit naar Fibroblasten Groeifaktor (FGF) en Vascular Endothelial Growth Factor (VEGF). Het is voorstelbaar dat het angiogenetisch effekt van een tumor in vitro samenhangt met de klinische prognose.

Remming van de angiogenese kan een belangrijke aanvullende mogelijkheid opleveren voor de behandeling van tumoren. In samenwerking met de afdeling Pathologie wordt gezocht naar de mogelijkheid om monoclonale antilichamen, gericht tegen angiogene groeifaktoren, te ontwikkelen. Er zijn een aantal geneesmiddelen bekend met een duidelijk angiostatisch effect, dat gemeten kan worden in vaatendotheelkweken. Dit onderzoek gebeurt in nauwe samenwerking met Prof. van Dam-Mieras van de afdeling Biochemie van de Open Universiteit te Heerlen.

\section{Adhaesiemoleculen, proteolyse}

In de cascade van gebeurtenissen van tumorgroei, angiogenese en metastasering, is er een essentieel moment, waarin tumorcellen vast gaan zitten op de basaalmembraan van de vaatwand, deze doorboren en in de bloedsomloop terecht komen. Voor dit vasthechten van tumorcellen zijn Integrines en Selectines nodig als adhaesiemoleculen. Om de vaatwand vervolgens doorlaatbaar te 
maken voor tumorcellen, wordt deze ten dele opgelost door enzymen, waarbij het elastinase een belangrijke rol speelt. In ons onderzoek naar prognostische faktoren zal worden gezocht naar de relatie tussen de meting van adhaesiemoleculen en elastinase in tumoren en de klinische prognose.

Het onderzoek naar de prognostische faktoren is niet beperkt tot het mammacarcinoom alleen. Ik heb dit voorbeeld gebruikt om de onderzoekslijn te illustreren. Ruud van Rijswijk zal van dezelfde technieken gebruik maken bij het onderzoek van het coloncarcinoom. Onder leiding van Harry Schouten gebeurt soortgelijk onderzoek bij het non-Hodgkin lymfoom, waarbij naast flowcytometrie meer in detail gekeken wordt naar de prognostische betekenis van chromosomale afwijkingen. Dit onderzoek gebeurt in samenwerking met de afdeling Moleculaire Celbiologie.

\section{Tussen Kos en Knidos, wikken en wegen}

Voorlopig zal de besluitvorming in de oncologie nog vooral berusten op stochastische, zo $\mathrm{U}$ wilt, statistische overwegingen. Bij de basisbehandeling van het primair mammacarcinoom laten wij ons leiden door een artikel in The Lancet, met statistische gegevens over het gerandomiseerd onderzoek bij 75.000 patiënten met een mammacarcinoom. Deze denkwijze heeft in de oncologie ook gezorgd voor een enorme verbetering. De 5-jaars overleving in Nederland is sinds 1958 verdubbeld. Wij bevinden ons met de stochastiek ook in goed gezelschap. Griekse filosofen uit de tijd van Hippocrates beschouwden de geneeskunde als een stochastische kunst. Op de kust van Klein-Azië, tegenover Kos, was echter de school van Knidos gevestigd. Daarin probeerde Ktesias ziektebeelden op een rationele, wetenschappelijke manier in te delen en te verklaren. Bij de stand van de wetenschap 400 jaar voór Christus bleek dit onbegonnen werk. Het Knidische systeem 
verzandde in dogma's en de school van Hippocrates op Kos maakte furore met een stochastische benadering. Pas nu komen deze scholen vooral dankzij de ontwikkelingen in de moleculaire biologie dichter bij elkaar, waardoor wikken en wegen in de werkelijke betekenis van de woorden mogelijk wordt. Wikken heeft dezelfde stam als wichelen, het doen van voorspellingen uit bepaalde tekens. Het wegen is het toekennen van het gewicht, het belang aan die tekens. Wikken en wegen is in die zin synoniem met het vaststellen van de prognose, op grond van metingen.

Ik had bij de jonge patiënte met een borstcarcinoom over meer argumenten willen beschikken dan de gemiddelde statistiek. Twee jaar na de operatie ontwikkelde zij ondanks behandeling met chemotherapie metastasen in het skelet. Wanneer ik de prognose betrouwbaarder had kunnen voorspellen, dan had ik haar een andere, waarschijnlijk intensievere vorm van behandeling geadviseerd. Het is nog niet zo ver dat de prognose per patiënt met zekerheid kan worden gemeten. Sommige wetenschapsfilosofen betwijfelen ook of dit vanwege de complexiteit van ieder mens wel ooit mogelijk zal worden, zoals ook het weer vanwege de complexiteit van de invloeden zich niet betrouwbaar laat voorspellen. Ik heb echter vertrouwen in het onderzoek, en ik hoop daaraan in Maastricht een steentje te kunnen bijdragen.

\section{Nawoord}

Tot besluit van mijn inaugurale rede wil ik graag dankbaarheid en waardering laten blijken. Mijn ouders en mijn familie dank ik voor de kansen die zij mij geboden hebben.

Het College van Bestuur van deze Universiteit dank ik voor mijn benoeming tot Hoogleraar en de Raad van Bestuur van het Academisch Ziekenhuis dank ik voor mijn aanstelling als internist. Het onderzoek heeft mij altijd gefascineerd en bezig gehouden, maar een behoorlijk deel van mijn hart ligt bij de patiëntenzorg. 
Voor een klinisch hoogleraar is die kombinatie een vanzelfsprekende noodzakelijkheid. Ik was en ben onder de indruk van het creatieve basale onderzoek van mijn leermeester Haanen, maar ik ben nog veel meer onder de indruk geraakt van de manier, waarop hij met patiënten omging en sprak.

Hooggeleerde Haanen, beste Clemens, ik hoop dat ik iets van jouw enthousiasme en liefde voor de geneeskunde kan overbrengen op de Maastrichtse studenten. Zij zullen er hun leven lang plezier van hebben.

Ruim 15 jaar heb ik mogen werken in én van de beste ziekenhuizen van Nederland, het Catharinaziekenhuis in Eindhoven. Ik ben de Maatschap van internisten in het Catharinaziekenhuis enorme dank verschuldigd voor de samenwerking en de vriendschap in die tijd. Met Wim Breed vormde ik, binnen de filosofie van de Maatschap van dubbele bezetting op de aandachtsgebieden, een ideaal duo.

Zeergeleerde Breed, beste Wim, aan jou heb ik veel te danken, wij spreken dezelfde taal.

Ik begin mij thuis te voelen in de Vakgroep Interne Geneeskunde hier in Maastricht. Met bewondering heb ik gekeken naar het vakmanschap en de deskundigheid, die over een breed gebied van de interne geneeskunde zijn ontwikkeld door een groep, die voor academische begrippen relatief klein is. Ik zal mij mede inzetten om van de Interne in Maastricht een breed gewaardeerde, en als het aan mij ligt, wat klassiek getinte School te maken.

De Werkgroep Haematologie-Oncologie beschouw ik als de parel aan de kroon van de Interne Werkgroep. Ik heb zeer veel waardering voor de manier, waarop Harry Schouten het hoofdschap van de afdeling vór mijn komst heeft waargenomen. De samenwerking in de Werkgroep verloopt mede door de inzet van het Hoofd van het Laboratorium Haematologie, Karly Hamulyák, en het vakkundig enthousiasme van Annemarie ten Haaft en Lizzy van Pampus, voortreffelijk en produktief 
Met verdriet bedank ik Guus Flendrig, die tot zijn overlijden in maart van dit jaar, het bezielende hoofd was van de Vakgroep Interne.

Hooggeleerde Flendrig, beste Guus, toen de tijd verstreek dacht ik het al, maar toen het moment voorbij was, wist ik het zeker, jij was van ons de enige echte afstammeling van Hippocrates, de vader van de geneeskunde.

Tenslotte, Tineke, Karlijn en Brieke, jullie laten mij leven, bij jullie vind ik mijn plataan.

Ik heb gezegd. 